\title{
Managing Students
}

\author{
By John M. Gledhill \\ Buckingham, UK: Open University Press, 1999, 140 pages
}

Reviewed by

\section{Todd Adams}

Managing Students is a quick read that attempts to guide faculty and staff through the complex world of university administration. With a seemingly endless number of issues to address, John Gledhill provides instruction for campus officials as they maneuver through the college environment. As a reference for good practice, Managing Students succeeds in that it covers many topics in concise, easy to comprehend sections. After a good forward by Paul D. Hartley and an introduction, each chapter is divided into sections that provide brief headings for quick use and referral.

As the academic registrar at Coventry University, John Gledhill uses English terms throughout his text. For the American reader, it is important to take time and make a quick study of the introductory chapter where terminology is explained or face being confused. Common American terms are replaced with English versions; for example, credit hours are modules, student orientation is induction, and paying is queuing.

Gledhill provides instruction for the college administrator in eight key areas:

- recruitment, retention and aftercare;

- course construction and module choice;

- examinations;

- award ceremonies and certificates;

- discipline;

- records and transcripts;

- financial and legal obligations; and

- confidentiality, data protection, references;

Although several topics relate to the student affairs professional, the book's primary focus is toward faculty and academic affairs administrators. For example, the chapter on award ceremonies begins with an interesting history of graduation proceedings in the United Kingdom and their role in higher education institutions. From that point, however, ceremonies are discussed in minute detail that will only benefit the academician involved with planning an institution's graduation. Items such as the purpose of academic dress, who should (and should not) be included in processionals, and the role each person plays during the event are covered extensively. Advice is also

Todd Adams is the Assistant Dean of Student Development and Dean of West Campus Residential Education at Duke University in Durham, NC. 
given concerning graduation locations and the design of certificates. Furthermore, the chapters on course construction and examinations are written with the faculty, staff, and administrators in mind who manage curriculum, set testing calendars and oversee cases of academic dishonesty.

The chapter titled "Financial and Legal Obligation" was a highlight of the text. Throughout, Gledhill provides meaningful observations of the university system in which each party (students and administrators) has a responsibility to the other. Of particular interest is Gledhill's assessment that students can expect some modicum of what he called "personal care" in return for payment of fees. The author wrote that "students have the right to a safe place to study" (p. 103). Yet Gledhill suggested institutions do not have to provide service above and beyond any normal service provider. Gone are the days of in loco parentis. The author is quick to point out, however, that "notwithstanding this, it would be a poor institution which did not provide significant advice to its students both on academic and on non-academic matters" (p. 103). According to Gledhill, these "fringe" benefits are not central to a university's service itself, but they do make an important difference in attracting students to one institution over another.

Managing Students may not resonate with all student affairs professionals. Although it provides a broad overview of everyday campus issues and may prove beneficial to the novice administrator, the book lacks specific guidance and instruction on resolving complex problems. In this format, Gledhill's book can not begin to address the myriad issues that faculty and staff face when working with students at institutions of higher learning. In addition, the book fails with its title. Managing Students is part of a series on college and university management practices. Structures such as institutions and organizations are manageable. Students, however, are not managed, no matter what one might think. 